\title{
A study to assess knowledge and attitude of infertile Kashmiri couples
}

\author{
Basharat Hussain Pandit ${ }^{1}$, Asif Mustafa ${ }^{1}$, Sadia Ali Wani2*, Fatima Nazir ${ }^{3}$
}

\author{
${ }^{1}$ Department of Obstetrics and Gynecology, J and K Health Services, Srinagar, Jammu and Kashmir, India \\ ${ }^{2}$ Department of Anaesthesia and Critical Care, GMC, Srinagar, Jammu and Kashmir, India \\ ${ }^{3}$ Medical officer, NHM, District Hospital Pulwama, Jammu and Kashmir, India
}

Received: 31 July 2020

Revised: 08 September 2020

Accepted: 09 September 2020

\author{
*Correspondence: \\ Dr. Sadia Ali Wani, \\ E-mail: sadiawani010@gmail.com
}

Copyright: () the author(s), publisher and licensee Medip Academy. This is an open-access article distributed under the terms of the Creative Commons Attribution Non-Commercial License, which permits unrestricted non-commercial use, distribution, and reproduction in any medium, provided the original work is properly cited.

\section{ABSTRACT}

Background: Infertility is defined as the inability to conceive naturally after one year of regular unprotected sexual intercourse. The chance to conceive depends on multiple factors like the length of sexual intercourse, frequency of coitus and age of couples. This could be due to male as well as female factors and deficiencies.

Methods: This is a cross sectional observational study conducted on infertility patients. A fertility questionnaire was designed for both the partners with questions covering knowledge and attitude towards infertility.

Results: A total 100 couples were selected in which prevalence of primary and secondary infertility was $72 \%$ and $28 \%$ respectively. The mean duration of infertility was 3 years. On scoring their level of knowledge, $52 \%$ had inadequate knowledge, $44 \%$ had moderate knowledge and $4 \%$ had adequate knowledge. There was no statistically significant difference in the knowledge in relation to their educational qualification and type of infertility among participants.

Conclusions: Infertility is common problem affecting $10-15 \%$ of the population. The knowledge about infertility and its risk factors is generally limited among the participants, in spite of their educational status.

Keywords: Attitude, Knowledge, Infertility, Rural

\section{INTRODUCTION}

Infertility, a disease of reproductive system affecting men and women with almost equal frequency. ${ }^{1}$ WHO has defined primary infertility as inefficiency to conceive after one year of unprotected sex and secondary infertility if not conceived following previous pregnancy. Infertility affects 8-12\% of couples worldwide during their reproductive lives (WHO, 1991). ${ }^{2}$

A global survey of almost 17,500 women of childbearing age from 10 different countries revealed that knowledge and biology of infertility was poor. ${ }^{3}$ Most of the women are not aware of their period of the month in which they are most fertile and when to seek medical advice. The risk factors for infertility include advanced maternal age, obesity, smoking, alcohol consumption, menstrual irregularities, sexually transmitted infections, and many others. ${ }^{4}$ Increasing awareness about these factors may aid in decreasing the incidence of fertility. Therefore, both partners should be made aware about these risk factors and patient education has been found to be an important factor in decreasing the psychological burden to those who are affected. ${ }^{5}$

Researches exploring the knowledge, behaviours, perceptions and practices regarding infertility or certain treatment options are present from the developed Nations but very limited literature is available from the developing countries like India despite high prevalence of infertility. 
The main aim of the present study was therefore to evaluate the knowledge of infertile couples attending to outpatient department (OPD) about the risk factors associated with infertility and to assess their attitude towards various methods of infertility treatment.

\section{Aims and objectives}

The primary objective was to assess the knowledge and attitude of infertile couples attending gynecological OPD. Secondary objective was to assess the possible risk factors and social consequences towards infertility.

\section{METHODS}

\section{Study design}

A prospective cross-sectional study was conducted.

\section{Study setting}

The study was conducted in the outpatient clinic at district hospital Shopian, Kashmir. All medical services were provided free of charge.

\section{Study participants and sampling technique}

100 participants were enrolled in this study from January 2019 to December 2019. The subjects who were willing to participate were chosen by simple random sampling.

\section{Data collection}

The study was based on an interview questionnaire. The questionnaire was initially designed by the research team according to a previously validated questionnaire Ali and Kjellberg. ${ }^{6,7}$ The interview questionnaire was translated into Urdu. Discussions with various relevant experts at district hospital confirmed the content validity and feasibility of the questionnaire to ensure relevance and clarity of the questions. Several additions and amendments were made to ensure that the questions were valid in a Kashmiri context.

A total 100 patients were recruited for this study. This is a prospective observational study conducted on infertile patients attending our rural hospital for a period of 1 year. Those couple's were recruited who were willing to answer the questionnaire. Informed consent was taken from all the participants and all were offered knowledge and attitude-based questionnaires during clinical history taking. The questionnaire contained 16 knowledge based and 7 attitude-based questions. The level of knowledge was assessed by giving a score 1 to correct answer, 0 for wrong and those do not know the answer. Those who scored $<50 \%$ were considered to have inadequate knowledge, those with scores $>50$ to $75 \%$ as moderately adequate and those with scores $>75 \%$ adequate knowledge regarding infertility.

\section{RESULTS}

The demographic data is shown in (Table 1). Mean age \pm SD of males and females were $30.87 \pm 4.168$ and $26.79 \pm 4.721$ respectively.

Table 1: Demographic data.

\begin{tabular}{|ll|}
\hline Parameters & \\
\hline \multirow{2}{*}{ Mean age of female (years) } & $\begin{array}{l}26.79 \pm 4.721 \\
\text { Range 20-45 }\end{array}$ \\
\hline \multirow{2}{*}{ Mean age of male (years) } & $\begin{array}{l}30.87 \pm 4.168 \\
\text { Range 25-48 }\end{array}$ \\
\hline \multirow{2}{*}{ Type of infertility N (\%) } & $\begin{array}{l}\text { Primary, } 72(72) \\
\text { Secondary, 28 }(28)\end{array}$ \\
\hline \multirow{2}{*}{ Mean duration of infertility } & $\begin{array}{l}\text { Primary, 2.29 } \pm 1.093 \\
\text { Secondary, } 4.73 \pm 1.78\end{array}$ \\
\hline
\end{tabular}

The response of couples towards risk factors associated with infertility is depicted in (Table 2).

Table 2: Response of couple about knowledge based questionnaire.

\begin{tabular}{|c|c|c|c|}
\hline Questions & Yes & No & Don't know \\
\hline Do you think increasing age in women may delay to achieve pregnancy? & 75 & 17 & 8 \\
\hline Does obesity in a women delay the fertility? & 77 & 10 & 13 \\
\hline $\begin{array}{l}\text { Do you think irregular cycle may be a cause for delay in achieving } \\
\text { pregnancy? }\end{array}$ & 80 & 9 & 11 \\
\hline $\begin{array}{l}\text { Does pain in lower abdomen during periods and during sexual intercourse } \\
\text { delays in pregnancy? }\end{array}$ & 20 & 35 & 45 \\
\hline What do you mean by fertile period in a women having regular cycle? & 55 & 39 & 6 \\
\hline $\begin{array}{l}\text { Do you think foul smelling discharge per vagina in a women is a cause for } \\
\text { pregnancy delay? }\end{array}$ & 18 & 26 & 56 \\
\hline Does OCP use in past delay conception in the women? & 48 & 13 & 39 \\
\hline Do you think frequency of intercourse increases the chance of pregnancy? & 61 & 24 & 15 \\
\hline $\begin{array}{l}\text { Does lying down in bed for long time after sexual intercourse increase the } \\
\text { pregnancy chance? }\end{array}$ & 70 & 14 & 16 \\
\hline
\end{tabular}




\begin{tabular}{|llll|}
\hline Questions & Yes & No & Don't know \\
\hline Do you think stressful life in a women affects her fertility? & 90 & 5 & 5 \\
\hline Do you think delay in pregnancy runs in families? & 33 & 37 & 30 \\
\hline Do you think exposure to environmental pollutant reduce fertility & 45 & 20 & 35 \\
\hline Do you think regular exercise by a women increases her fertility? & 77 & 10 & 13 \\
\hline Does smoking reduce sperm parameters in men? & 50 & 29 & 21 \\
\hline Do you think increasing age in men reduces fertility? & 57 & 26 & 17 \\
\hline $\begin{array}{l}\text { Do you think a women conceived previously might have problems to conceive } \\
\text { again? }\end{array}$ & 31 & 53 & 16 \\
\hline
\end{tabular}

Table 3: Response of couple about attitude based questionnaire.

\begin{tabular}{|llll|}
\hline Questions & Yes & No & \multicolumn{1}{c|}{$\begin{array}{l}\text { Don't } \\
\text { Know }\end{array}$} \\
\hline Do you think infertility is a disease? & 70 & 30 & B- 16 \\
\hline Who do you think it should be investigated first? & $\mathrm{H}-3$ & $\mathrm{~W}-81$ & $\mathrm{~B}-7$ \\
\hline Who is being blamed for infertility in the society? & $\mathrm{H}-1$ & $\mathrm{~W}-92$ & 10 \\
\hline Do you think it is socially acceptable to have a test tube baby? & 5 & 85 & 5 \\
\hline If a couple cannot have a child, do you think they should adopt? & 12 & 83 & 22 \\
\hline $\begin{array}{l}\text { Do you think your husband should donate sperm to help an infertile couple } \\
\text { to have a baby? }\end{array}$ & 8 & 70 & 24 \\
\hline $\begin{array}{l}\text { Are you interested to donate your egg to help an infertile couple to have a } \\
\text { baby? }\end{array}$ & 7 & 69 & $\mathrm{~B}-16$ \\
\hline & & & 16 \\
\hline
\end{tabular}

In present study, more than $70 \%$ of respondents were well aware about the common risk factors such as advanced age, obesity, irregular menstrual cycle, stress, advantages of regular exercise. But only $55 \%$ were not aware about fertile period. In present study, 50\% were aware that smoking reduces the sperm parameters in men and $57 \%$ were aware that increased age in men also reduces fertility. The response of couples about attitudebased questionnaire is shown in (Table 3). In current study, $70 \%$ of couples believed infertility is a disease. Only $15.5 \%$ knew that it was a problem of the couple and needed investigation of the couple simultaneously. In current study, $91.5 \%$ of females were blamed by the family members and the society in spite of the fact that the cause may be related to any one of the partners. The level of knowledge of participants is shown in (Table 4).

Table 4: Levels of knowledge.

\begin{tabular}{|ll|}
\hline Knowledge & N (\%) \\
\hline Inadequate knowledge & $52(52)$ \\
\hline Moderately adequate knowledge & $44(44)$ \\
\hline Adequate knowledge & $4(4)$ \\
\hline
\end{tabular}

\section{DISCUSSION}

In the present study, the data identified significant knowledge gaps and misconceptions surrounding the infertility and reproductive health. Many women have limited understanding regarding risk factors related to conception and infertility.
According to Boivin et al 2007, knowledge about fertility issues is a core motivator for fertility problems. ${ }^{8}$ A global survey revealed inadequate knowledge of women regarding infertility. ${ }^{3}$ This study also demonstrated that the couples had inadequate knowledge about the risk factors that are associated with infertility.

In present study, $75 \%$ of female partners were aware that increasing age is one of the factors responsible for infertility which is similar to study by Boivin et al, but there was lack of awareness of the significance of age for declining fertility among childless Canadian women and Australian women and among the University students in Sweden. ${ }^{8-11}$

In this study, $77 \%$ were aware that obesity has role in infertility which is similar to Abolfotouh et al, Brannian et al, Bunting et al study and Daniluk et al study. , $^{8,12,13}$

In present study, $81 \%$ of women were aware that irregular menstrual cycles may be a cause for delay in pregnancy, but in Abolfotouh et al study only 64\% were aware about it. ${ }^{12}$

It is very important for women to know about the fertile period and when exactly the couple should try to conceive. In this study, only $55 \%$ were aware about their fertile period which was similar to Ali et al in which $48 \%$ were aware of fertile period. ${ }^{14,15}$ 
In this study more than $80 \%$ of female partners were not aware about the genital tract infections as risk factor for infertility. Since, diagnosis and treatment of genital tract infections can prevent the major sequel, the tubal block, awareness of genital infection as a risk factor is highly required in our society.

In our study, $48 \%$ had misconception that use of oral contraceptive affect their fertility status and $38 \%$ were not aware about the OCP role, this misconception may have led to unwanted pregnancy loss, but in Ali et al study, $61 \%$ correctly highlighted use of OCP affecting the fertility. Study conducted by Bunting also highlighted that participants had a false belief that use OCP as risk factor for infertility. ${ }^{5,15}$

In this study, $70 \%$ of the respondents had the false belief that the chances of pregnancy increase after lying down in bed for long time after sexual intercourse, which is similar to Boivin et al study in which participants believed in the myth that lying down for 10 minutes after sexual intercourse increases the pregnancy rate. ${ }^{5}$

In current study, 90\% females knew about the negative effect of stress on fertility, which is similar to other studies. ${ }^{5,8,9}$ In current study, only $33 \%$ of couple belief that infertility runs in family but no other study commented on hereditary nature of fertility. In our study, $56.5 \%$ women thought that increasing man's age reduces the chance of infertility, which is similar to Koert et al study. ${ }^{9}$ In present study, 52\% women had the misconception there will be no problem for further conception; due to this false belief there was delay in their consultation. Considering attitude of people in this study, $70 \%$ labelled infertility as disease, but in Ali et al study, only $44 \%$ opined that infertility as disease. ${ }^{15}$ In the present study, $90 \%$ of women were blamed by the society for infertility and this is similar to Ali et al and Sami et al studies. ${ }^{15,16}$ In this study, $70 \%$ of infertile couple's husbands were not willing to help infertile couple by sperm donation and this is similar to Sohrabvand et al study were $98.7 \%$ opposed sperm donation. ${ }^{17}$ In our study response of infertile females towards egg donation was poor, but in a study conducted in Turkey by Isikoglu et al the proportion of positive respondents towards oocyte donation was nearly $85 \% .^{18}$

\section{CONCLUSION}

Infertility is common problem affecting $10-15 \%$ of the population. The knowledge about infertility and its risk factors is generally limited among the participants, in spite of their educational status. We should create effective strategies for improving the awareness and education regarding fertility by conducting counselling sessions, interactive classes and web based and media based education.

Funding: No funding sources Conflict of interest: None declared
Ethical approval: The study was approved by the Institutional Ethics Committee

\section{REFERENCES}

1. Callahan LT, Caughey AB. Infertility and assisted reproductive technologies. Blueprints Obstetrics and Gynecology. 5th Edition. Philadelphia: Lippincott Williams \& Wilkins; 2007.

2. World Health Organization, Infertility: tabulation of available data on prevalence of primary and secondary infertility. Available at https://apps.who. int/iris/handle/10665/59769. Accessed on 20 June 2020.

3. Bunting L, Tsibulsky I, Boivin J. Fertility knowledge and beliefs about fertility treatment: findings from the International Fertility Decision-making Study. Human Reproduction. 2013;28(2):385-97.

4. Namujju J. Knowledge, attitudes and practices towards infertility among adults 18-40 years in Kalisizo, Rakai District in Uganda. Available at: http://makir.mak.ac.ug/handle/10570/1705. Accessed on 20 June 2020.

5. Bunting L, Boivin J. Knowledge about infertility risk factors, fertility myths and illusory benefits of healthy habits in young people. Hum Reprod. 2008; 23(8):1858-64.

6. Ali S, Sophie R, Imam AM, Khan FI, Ali SF, Shaikh A, et al. Knowledge, perceptions and myths regarding infertility among selected adult population in Pakistan: a cross-sectional study. BMC Public Health. 2011;11:760.

7. Kjellberg S, Sydsjö G, Glebe K, Sundelid M. Knowledge of and attitudes towards infertility held by members of two county councils in Sweden. Acta Obstet Gynecol Scand. 2000;79(11):1015-20.

8. Bunting L, Boivin J. Decision-making about seeking medical advice in an internet sample of women trying to get pregnant. Hum Reprod. 2007;22(6): 1662-8.

9. Judith C, Daniluk EK, Cheung A. Childless women's knowledge of fertility and assisted human reproduction: identifying the gaps. Fertil Steril. 2012;97(2):420-6.

10. Hammarberg K, Setter T, Norman RJ, Holden CA, Michelmore J, Johnson L. Knowledge about factors that influence fertility among Australians of reproductive age: a population-based survey. Fertil Steril. 2013;99(2)502-7.

11. Skoog A, Svanberg C, Lampic PO, Tydén KT. Attitudes toward parenthood and awareness of fertility among postgraduate students in Sweden. Gend Medi. 2006;3(3)187-95.

12. Mostafa AA, Alabdrabalnabi RB, Al-Jughaiman AU, Hassan SN. Knowledge, attitude, and practices of infertility among Saudi couples. Int J Gen Med. 2013;6:563-73.

13. Brannian J D. Obesity and fertility. S D Med. 2011; 64(7):251-4. 
14. Bunting L, Tsibulsky I, Boivin J. Fertility knowledge and beliefs about fertility treatment: findings from the International Fertility Decision-making Study. Hum Reprod. 2013;28(2):385-97.

15. Ali S, Raafay S, Imam AM, Khan FI, Ali SF, Shaikh A. Knowledge, perceptions and myths regarding infertility among selected adult population in Pakistan: a cross-sectional study. BMC Public Health. 2011;11:760.

16. Sami N, Ali TS. The cultural politics of gender for infertile women in Karachi, Pakistan: Proceedings of the FOTIM gender studies conference, Pakistan; Pretoria, South Africa. 2006.

17. Schmidt L. Infertile couples assessment of infertility treatment. Acta Obstet Gynecol Scand. 1998;77(6): 649-53.
18. Isikoglu M, Senol Y, Berkkanoglu M, Ozgur K, Donmez L, Stones-Abbasi A. Public opinion regarding oocyte donation in Turkey: first data from a secular population among the Islamic world. Human Reprod. 2006;21(1):318230268-1161, 146023.

Cite this article as: Pandit $\mathrm{BH}$, Mustafa $\mathrm{A}$, Wani SA, Nazir F. A study to assess knowledge and attitude of infertile Kashmiri couples. Int J Reprod Contracept Obstet Gynecol 2020;9:4192-6. 